\title{
Effect of aluminum in Bacillus megaterium nickel resistance and removal capability
}

\section{Efecto del Aluminio sobre la Resistencia y la capacidad de remoción de Ni de Bacillus megaterium}

\author{
Andrea M. Rivas-Castillo, María Elena Guatemala-Cisneros, Norma G. Rojas-Avelizapa*
}

Centro de Investigación en Ciencia Aplicada y Tecnología Avanzada del IPN, Cerro Blanco 141, Col. Colinas del Cimatario, Querétaro, Qro. 76090, Mexico. Phone: +52 (442) 2290804 Ext. 81031.

*Corresponding author.

E-mail address: nrojasa@ipn.mx (N. G. Rojas-Avelizapa).

Received: 12 December 2016 / Received in revised form: 31 May 2017 / Accepted: 26 June 2017 / Published online: 1 July 2017.

https://doi.org/10.29267/mxjb.2017.2.2.206

\begin{abstract}
The increasing water pollution by heavy metals is considered an alarming situation worldwide, due to the adverse impact they cause in ecosystems and human health. Although conventional techniques are available to diminish the metal concentration present in water bodies, they offer disadvantages, like inefficient metal removal, toxic sludge generation, and high operating costs. In contrast, biotechnological approaches may render a viable alternative, since they offer lower environmental impacts and operating costs, and also higher removal efficiencies when metals are present in small concentrations. It has been shown that the simultaneous presence of more than one metal can generate synergistic, additive or antagonistic effects, thus affecting their removal, and it has been previously demonstrated that $B$. megaterium strain MNSH1-9K-1 possesses the ability to remove metals present in liquid and solid wastes. Therefore, the goal of the present work was to study $B$. megaterium MNSH1-9K-1 Ni resistance and removal properties in liquid medium, and to evaluate the variation of these abilities in the presence of another toxic metal, namely $\mathrm{Al}$, which is also commonly found in liquid wastes. To this end, $B$. megaterium was grown in LB medium with the addition of $\mathrm{Ni}$ and/or $\mathrm{Al}$ at diverse concentrations, and both metal resistance and $\mathrm{Ni}$ removal capabilities were assayed by viable count, and Inductively Coupled Plasma Optical Emission Spectrometry (ICP-OES), respectively. The results obtained strongly suggest that B. megaterium MNSH1-9K-1 presents more susceptibility to $\mathrm{Ni}$ than to $\mathrm{Al}$, and that $\mathrm{Ni}$ removal is enhanced by the presence of $\mathrm{Al}$.
\end{abstract}


Keywords: B. megaterium, Biotreatment, Metal resistance, Ni removal.

\section{RESUMEN}

El incremento en la contaminación de agua por metales pesados es considerada una situación alarmante a nivel mundial, debido al impacto adverso que éstos generan en los ecosistemas y en la salud humana. Las técnicas convencionales para disminuir la carga de metales presentan desventajas, como son: la incompleta remoción de los metales, la producción de lodos tóxicos y los altos costos de operación. En contraste, los enfoques biotecnológicos representan una alternativa, ya que se consideran más amigables con el ambiente, tienen costos de operación menores y la eficiencia de remoción de metales es mayor cuando éstos se presentan en bajas concentraciones. Anteriormente se ha demostrado que la presencia simultánea de más de un metal puede generar efectos sinérgicos, aditivos o antagónicos, afectando así su remoción, y también ha sido reportada la habilidad de $B$. megaterium MNSH1-9K-1 para remover metales. Por ello, el objetivo del presente trabajo fue analizar las propiedades de resistencia y remoción de Ni de la cepa MNSH1-9K-1 en medio líquido, así como evaluar la variación de dichas propiedades en presencia de Al, también considerado como un metal tóxico comúnmente encontrado en los residuos industriales. Para ello, B. megaterium fue crecida en medio LB con la adición de Ni y/o Al en diversas concentraciones, analizándose tanto la resistencia como la capacidad de remoción de $\mathrm{Ni}$, por medio de cuenta viable y Espectrometría de Emisión Óptica por Plasma Acoplado Inductivamentente (ICP-OES), de forma respectiva. Los resultados obtenidos sugieren fuertemente que $B$. megaterium MNSH1-9K-1 presenta una mayor susceptibilidad a Ni que a Al, y que la remoción de Ni es promovida por la presencia de Al.

Palabras clave: B. megaterium, Biotratamiento, Resistencia a metales, Remoción de Ni.

\section{INTRODUCTION}

Heavy metals occur as natural constituents of the earth crust. In rocks, they exist as their ores in different chemical forms, from which they are recovered as minerals (Rubinstein \& Barsky 2002). However, the increasing contamination of heavy metals into the soil and waters due to human activities has created an environmental alarming situation and a major health concern worldwide, as they cannot be broken down to non-toxic forms, and therefore have long-lasting effects on ecosystems (Hernández et al., 1998; Ceribasi \& Yetis 2004; Monachese et al., 2012). Anthropogenic metal sources include: wastewater arising from informal settlements (Jackson et al., 2009), leachates from domestic and industrial landfill sites (Moodley et al., 2007), industrial wastes (Kamaldeep et al., 2011), disposal of metalcontaining industrial effluents (Phuong et al., 1998), mining activities (Eisler 1998; Duruibe et al., 2007), effluent from storage batteries and automobile exhaust (Verma \& Dubey 2003; Dogan et al., 2009), and the manufacturing and inadequate use of fertilizers, pesticides, etc. (Tsezos \& Volesky 1981; McConnell \& Edwards 2008). Through rivers and streams, metals are transported as either dissolved species in water or as an integral part of suspended sediments, and may then contaminate superficial water bodies or seep into the 
underground contaminating water from underground sources, particularly wells (Duruibe et al., 2007).

Hence, it is necessary to establish efficient methods to minimize or even eliminate metals prior to its discharge to the environment. Conventional approaches to reduce heavy metal contamination in water include: 1) chemical precipitation or flocculation, followed by sedimentation and disposal of the resulting sludge; 2) ion exchange; 3) adsorption by minerals, industrial byproducts, polymeric materials or agricultural wastes; 4) membrane filtration; 5) electrotreatments; 6) evaporation; and 7) photocatalytic processes (Barakat 2011). However, these processes present significant disadvantages, as incomplete removal, production of toxic sludge, high costs due to high-energy requirements, and the need of skilled technicians (Eccles 1999).

Thus, biotechnological processes are an innovative and promising technology available for the removal of heavy metals and its recovery from polluted water and lands, proved as an effective eco-friendly and economically feasible technology (Ameer Basha \& Rajaganesh 2014; Coelho et al., 2015), due to their low costs and higher efficiency at low metal concentrations, where physicochemical removal methods fail (Mejáre \& Bülow 2001; Perpetuo et al., 2011).

Among the heavy metals found as water pollutants, Nickel (Ni) and Aluminum (Al) are considered as highly valuable metals, used in numerous industrial processes. Specifically, $\mathrm{Ni}$ is employed for the fabrication of alloys, coatings, batteries, and some other uses, such as kitchen wares, mobile phones, jewelry, medical equipment, transport, buildings construction, and power generation (Keim 1990; Cempel \& Nikel 2006). Although Ni has biological activity in bacteria at nanomolar concentrations, being an essential component of the enzymes particularly involved in ureolysis, hydrogen metabolism, methane biogenesis and acetogenesis (Bartha \& Ordal 1965; Olson et al., 2001; Mulrooney \& Hausinger 2003), it is considered as a highly toxic metal (Cempel \& Nikel 2006), which treatment is important due to their hazardous nature, and even more, its presence in solid and liquid residues represents a valuable source for metal recovery.

It is known that essential and non-essential heavy metal ions at toxic levels bind to cellular structures, causing destabilization of these structures and of biomolecules (cell wall enzymes, DNA and RNA), thus inducing replication defects and cellular malfunctioning (Perpetuo et al., 2011). Microorganisms have developed diverse strategies for their survival in heavy metal-polluted habitats, including detoxifying mechanisms such as biosorption, bioaccumulation, biotransformation and biomineralization. Several factors may influence metal uptake, such as type of metal, their concentration and availability, degree of exposure, temperature, nature of the medium, salinity, and the specific metal removal capabilities of the microorganism used (Coelho et al., 2015; Dixit et al., 2015). Although metal combined effects has been scarcely studied (Crafford \& Avenant-Oldewage 2010; Fierros-Romero et al., 2016 b), synergistic or additive joint actions of metals have been documented (Enserink et al., 1991; Palaniappan \& Karthikeyan 2009), and antagonistic interactions may also occur (Kwong \& Niyogi 2009).

Previous studies show that the members of the genus Bacillus present high tolerance to heavy metals (Yilmaz 2003; Singh et al., 2010, 2013; Elsilk et al., 2014). However, although Bacillus metal resistance has been documented for different species (KamalaKannan \& Jae Lee 2008), few experiments have been performed regarding the effect on resistance of a combination of metals in liquid medium (Margaryan et al., 2013; FierrosRomero et al., 2016 b). In particular, it has been reported that B. megaterium possesses an 
intrinsically high level of resistance to hostile conditions (Salgaonkar et al., 2013; Pal et al., 2014) and metal exposition (e.g. Hg and Ni) (Narita et al., 2003; Rajkumar et al., 2013), among other preeminent properties like its morphological and molecular characteristics, which confer this microorganism with the capacity to produce metabolites of industrial relevance (Vary et al., 2007), and the ability to accumulate and chelate metals (Sharma et al., 2016). Because of this latter capacity, B. megaterium has been used for the biological treatment of high metal content wastes like phosphogypsum waste (Stefanescu 2015) and spent catalysts (Gómez-Ramírez et al., 2014; Arenas-Isaac et al., 2016).

Among the few previous reports regarding Bacillus resistance in the presence of metal mixtures, results have shown that Bacillus megaterium strain MNSH1-9K-1 possesses the ability to tolerate up to $200 \mathrm{ppm}$ of each $\mathrm{Ni}$ and $\mathrm{V}$ contained together in liquid media (Fierros-Romero et al., 2016 b). Also, it was observed that this strain presents the capability of removing $15.38 \pm 1.30 \mathrm{ppm}$ of $\mathrm{Ni}$, and $32.06 \pm 1.08 \mathrm{ppm}$ of $\mathrm{V}$ from PHGII liquid medium with $200 \mathrm{ppm}$ of each $\mathrm{Ni}$ and $\mathrm{V}$, corresponding to a removal of $7.69 \pm 0.65 \%$ of $\mathrm{Ni}$ and $16.03 \pm 0.54 \%$ of V (Fierros-Romero et al., $2016 \mathrm{~b}$ ).

Thus, the current study analyzed the potential of $B$. megaterium strain MNSH1-9K-1 to remove $\mathrm{Ni}$ from liquid medium at different concentrations, as well as the changes in $\mathrm{Ni}$ resistance and removal ability of this strain in the presence of another toxic metal: Al. The results presented may contribute to the knowledge of how the metal resistance and removal abilities of a microorganism may vary in the presence of more than one metal, which may be a common situation in the case of contaminated waters.

\section{MATERIALS AND METHODS}

\subsection{Bacterial strain and growth conditions}

Bacillus megaterium strain MNSH1-9K-1 (GenBank accession number KM654562.1) was used for this study, which isolation from a high metal content site has been previously described (Arenas-Isaac et al., 2016). LB liquid medium was used for microbial growth at $200 \mathrm{rpm}$ and $37^{\circ} \mathrm{C}$. Inoculums were prepared overnight, and microbial density was adjusted to an O.D. $600 \mathrm{~nm}=0.1$ to begin experimentation.

\subsection{Metal resistance}

Cultures were grown for 48 hours in $125 \mathrm{ml}$ Erlenmeyer flasks containing $10 \mathrm{ml}$ of LB liquid medium and different concentrations of $\mathrm{Al}, \mathrm{Ni}$, or both metals, in the ranges of 25 to $200 \mathrm{ppm}$, provided as $\mathrm{AlCl}_{3}$ and $\mathrm{Ni}\left(\mathrm{NO}_{3}\right)_{2} \cdot 6 \mathrm{H}_{2} \mathrm{O}$, respectively, as specified for each experiment. Also, samples without metals were included, as controls. Viability was assessed by taking a $100 \mu \mathrm{l}$ aliquot from each culture, and serial 10 -fold dilutions were prepared in phosphate-buffered saline (PBS) buffer (Nicholson \& Setlow 1990), and plated on LB solid medium. Finally, LB plates were incubated for $24-48 \mathrm{~h}$ at $37{ }^{\circ} \mathrm{C}$ to perform colony counting.

\subsection{Metal removal from liquid medium}


Experimental sets were prepared in $125 \mathrm{ml}$ Erlenmeyer flasks containing LB liquid medium supplemented with different concentrations of one or both metals [provided as $\mathrm{AlCl}_{3}$ and $\mathrm{Ni}\left(\mathrm{NO}_{3}\right)_{2} \cdot 6 \mathrm{H}_{2} \mathrm{O}$ ], to $10 \mathrm{ml}$ final volume. Also, samples without metals were included, as controls. After 48 hours of growth at $37^{\circ} \mathrm{C}$ and $200 \mathrm{rpm}$, the liquid phase of each sample was filtered using a cellulose acetate syringe filter (Alltech, Deerfield, IL, USA). Subsequently, the samples were acid digested. For this purpose, $1 \mathrm{ml}$ samples were placed in cylindrical silicon carbide vials, and $6 \mathrm{ml}$ of concentrated $\mathrm{HNO}_{3}$ and $2 \mathrm{ml}$ of concentrated $\mathrm{HCl}$ were added, and samples were digested in a microwave reaction system (Multiwave PRO, Anton Paar), using an HF100 rotor. Digestion conditions were: $600 \mathrm{~W}$ for 6 vessels, $40 \mathrm{bar}, 210-240^{\circ} \mathrm{C}$, with pRate of $0.3 \mathrm{bar} \mathrm{sec}^{-1}$, ramp $15 \mathrm{~min}$, hold $15 \mathrm{~min}$, and cooling $15 \mathrm{~min}$. Afterwards, $20 \mathrm{ml}$ of deionized water was added to the cylindrical vial, and the supernatant was collected and filled up to $100 \mathrm{ml}$ with deionized water. Metal analysis was performed at $231.604 \mathrm{~nm}$ for $\mathrm{Ni}$ and $396.152 \mathrm{~nm}$ for Al by ICP-OES (Varian Model 710-ES). Metal concentrations were calculated based on a calibration curve covering 0.1-10 mg kg-1, using a commercial standard (High-Purity, cat. \# ICP-200-7-6) (FierrosRomero et al., 2016 b).

\subsection{Statistical analysis}

Basic statistical parameters and analysis of variance (ANOVA) were performed using the commercial statistical software OriginPro 9.0. Differences with $P$ values of $\leq 0.05$ were considered statistically significant.

\section{RESULTS}

\subsection{Effect of $\mathrm{Al}$ and $\mathrm{Ni}$ on cell resistance}

To investigate the resistance of $B$. megaterium MNSH1-9K-1 to different concentrations of $\mathrm{Ni}$ and $\mathrm{Al}$, the strain was grown at $37^{\circ} \mathrm{C}$ and $200 \mathrm{rpm}$ for 48 hours in $125 \mathrm{ml}$ Erlenmeyer flasks containing $10 \mathrm{ml}$ of LB liquid medium, and diverse $\mathrm{Al}$ or Ni concentrations. As it can be observed in Fig. 1, the median lethal concentration $\left(\mathrm{LC}_{50}\right)$ and the 90 lethal concentration $\left(\mathrm{LC}_{90}\right)$ for $\mathrm{Al}$ were found when adding $147.25 \pm 1.77 \mathrm{ppm}$ and $150.50 \pm 0.71$ ppm, respectively. In the other hand, the $\mathrm{LC}_{50}$ for $\mathrm{Ni}$ is achieved with $75.5 \pm 3.53 \mathrm{ppm}$, and LC90 is caused by $96.25 \pm 1.77 \mathrm{ppm}$ of the metal.

To investigate the resistance of $B$. megaterium MNSH1-9K-1 to different concentrations of a Ni-Al mixture, the strain was exposed to diverse concentrations of both metals, in the mixtures indicated in Fig. 2. As could be expected, cell viability loss was observed in every condition tested, in comparison to the control without metals. A 20-fold decrement in resistance was observed when the strain was exposed to mixtures were Al prevailed in proportions of $125 / 5(25: 1)$ and $100 / 10$ (10:1) $\mathrm{Al} / \mathrm{Ni} \mathrm{ppm}$, respectively, or when Ni concentration increased to $75 \mathrm{ppm}$, in the mixture of 25/75 Al/Ni ppm. Also, it was shown that a mixture of 50/50 Al/Ni ppm caused a similar fold decrement in cell viability. When cells were exposed to 75/25 Al/Ni ppm, cell viability presented an 80-fold decrement, and the highest cellular death was obtained in the cultures that were exposed to the combined effect $\mathrm{Al} / \mathrm{Ni}$ of $10 / 100 \mathrm{ppm}(1: 10)$, and 5/125 ppm (1:25), exhibiting up to 170-fold and 
500-fold viability loss, respectively. Samples with only Al or Ni in $175 \mathrm{ppm}$ were also included in Fig. 2 to compare cell viability, showing a 22-fold, and 167-fold lessening in this parameter, respectively.

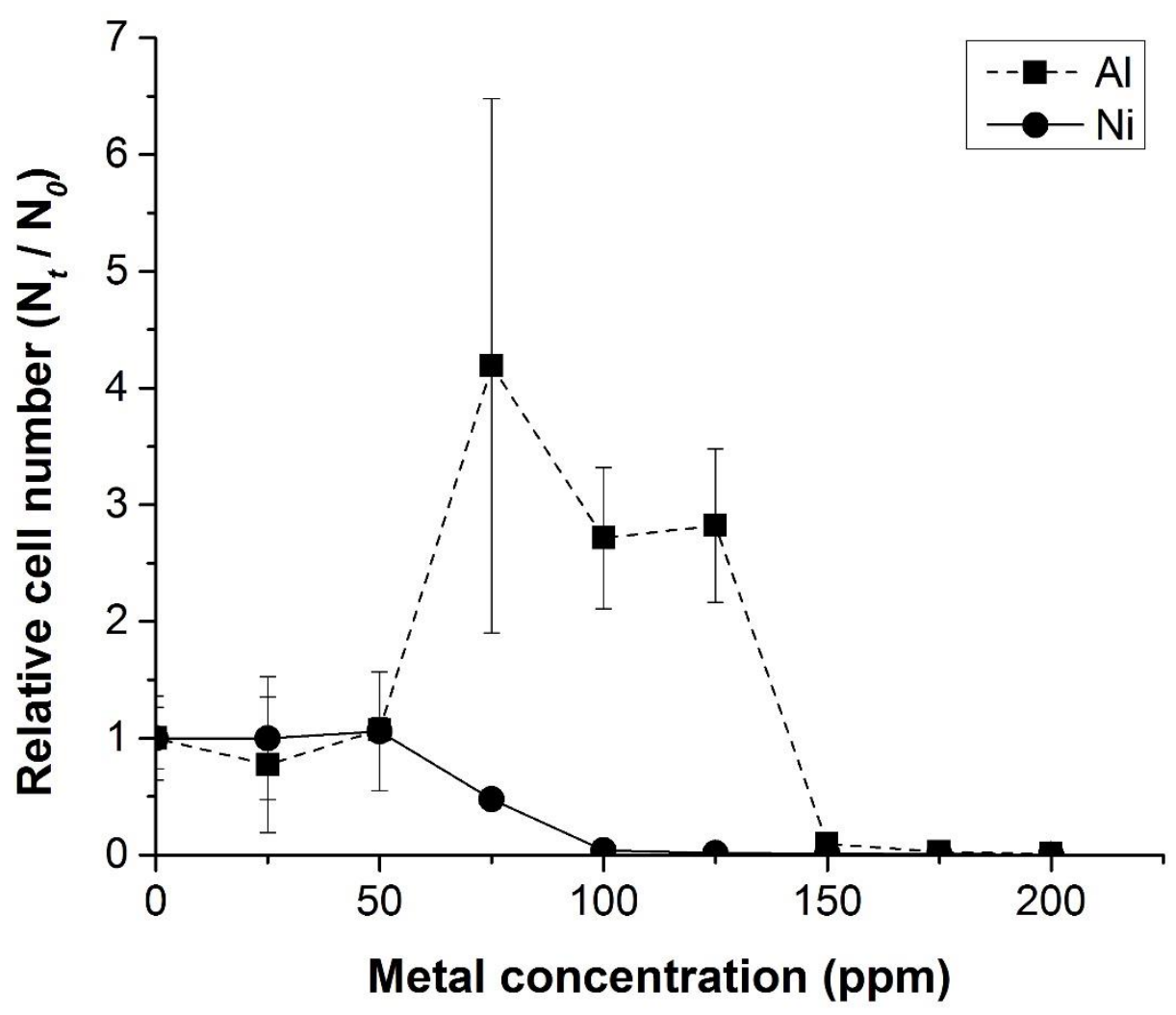

Fig. 1. Resistance of $B$. megaterium $\mathrm{MNSH} 1-9 \mathrm{~K}-1$ to $\mathrm{Al}$ and $\mathrm{Ni}$. The strain was grown in $\mathrm{LB}$ liquid medium in the presence of $\mathrm{Al}$ or $\mathrm{Ni}$ at the concentrations indicated (0 to 200 $\mathrm{ppm}$ ), and the results were normalized to those from the control (without metal). Data are presented as averages \pm standard deviations $(n=4)$.

\subsection{Assessment of B. megaterium metal removal ability}

In order to evaluate the ability of $B$. megaterium to remove $\mathrm{Ni}$ from liquid medium containing different concentrations of this metal, the strain was grown in LB liquid medium under the conditions described in Materials and Methods, and diverse Ni concentrations were added to the samples. The results showed that B. megaterium MNSH1-9K-1 was unable to remove Ni under any of the conditions tested (data not shown).

It has been documented that $\mathrm{Al}$ and $\mathrm{Ni}$ may appear together as contaminants of liquid and solid wastes from the metal-mechanic sector, automotive industry, petroleum refining processes, among other anthropogenic activities. So, to further investigate if MNSH1-9K-1 was able to remove $\mathrm{Ni}$ in the presence of another toxic metal, namely $\mathrm{Al}$, the strain was grown in the presence of both metals, at the same mixture concentrations used to evaluate resistance (Fig. 2). The data shown are the results of the subtraction of the concentration 
(ppm) of each element at to minus the remained $\mathrm{Ni}$ concentration (ppm) at the end of experimentation. Also, Ni removal in the abiotic control $(0.139 \pm 0.094 \mathrm{ppm})$ was subtracted from the data to obtain final removal at each condition tested.

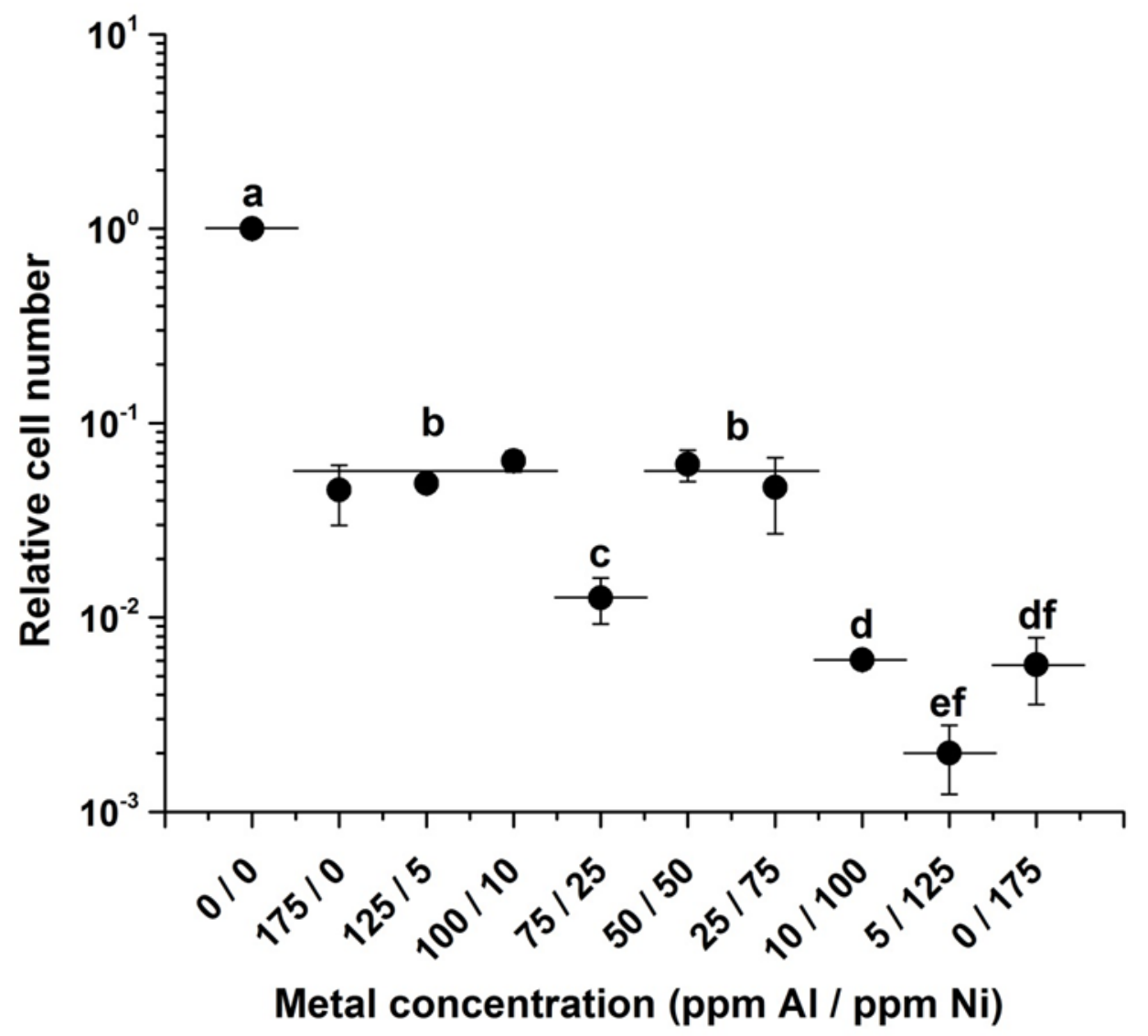

Fig. 2. Resistance of $B$. megaterium $\mathrm{MNSH} 1-9 \mathrm{~K}-1$ to $\mathrm{Al} / \mathrm{Ni}$ mixtures. The strain was grown in $\mathrm{LB}$ liquid medium in the presence of $\mathrm{Al}$ and $\mathrm{Ni}$, and the results were normalized to those from the control (without metals). Data are presented as averages \pm standard deviations $(n=4)$.

Surprisingly, B. megaterium was able to remove $\mathrm{Ni}$ when $\mathrm{Al}$ was present (Fig. 3), and this $\mathrm{Ni}$ removal extent tended to increase with the diminishing concentration of $\mathrm{Al}$, coupled with $\mathrm{Ni}$ increase, from $1.65 \pm 0.15$ in $125 / 5$ (25:1) to $7.12 \pm 0.85$ in $25 / 75$ (1:3) $\mathrm{Al} / \mathrm{Ni} \mathrm{ppm}$, until the highest Ni uptake of $10.75 \pm 1.91 \mathrm{ppm}$ was reached in the mixture of $10 / 100$ (1:10) $\mathrm{Al} / \mathrm{Ni}$ ppm, and then lowering again to $4.20 \pm 1.24$ in $5 / 125(1: 25) \mathrm{Al} / \mathrm{Ni} \mathrm{ppm}$. 


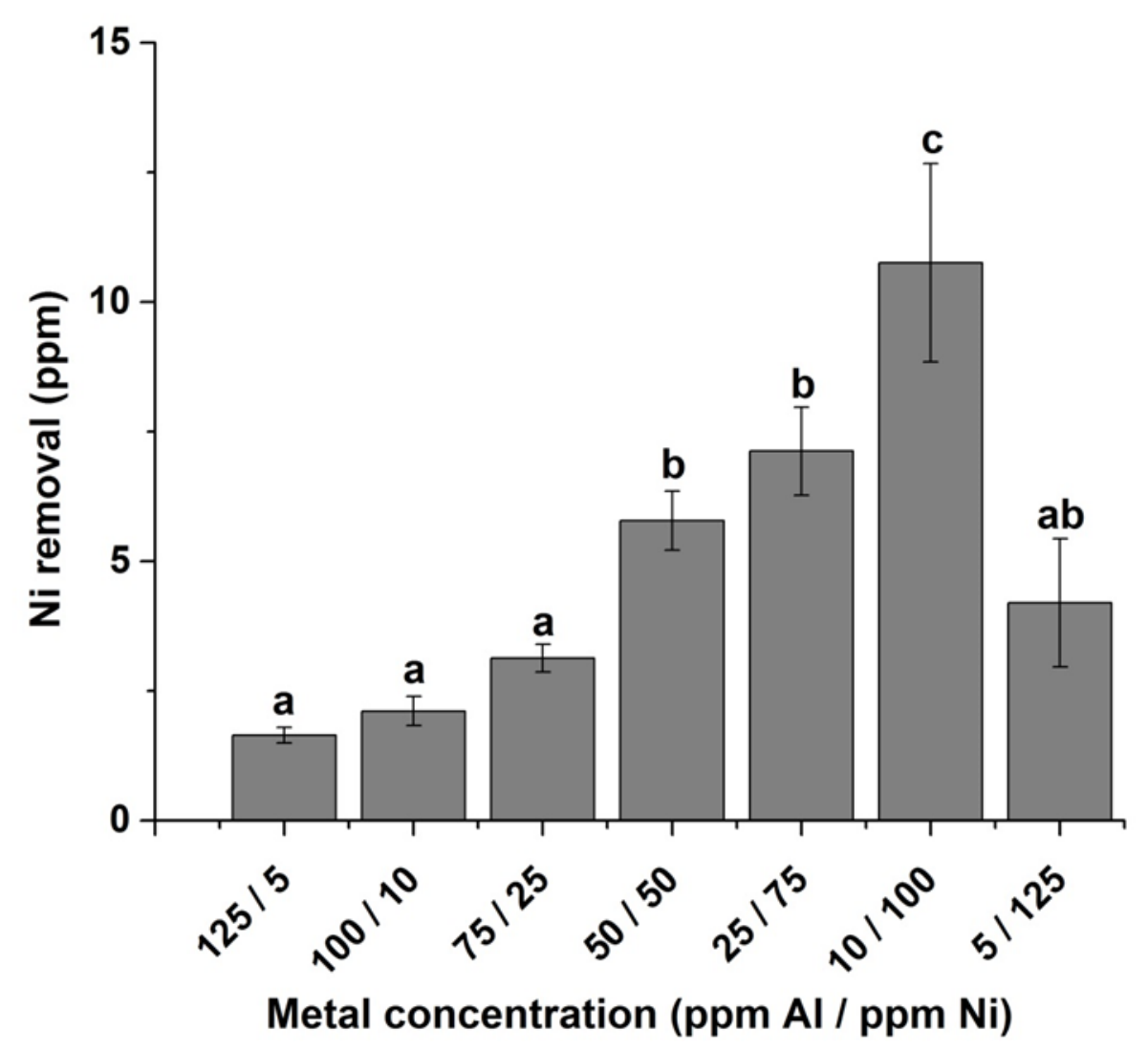

Fig. 3. Removal of Ni in the presence of Al. B. megaterium MNSH1-9K-1 was grown in LB liquid medium in the presence of different $\mathrm{Al} / \mathrm{Ni}$ mixtures. Data are presented as averages \pm standard deviations $(n=2)$, and lowercase letters indicate groups of data that were not significantly different by ANOVA $(P>0.05)$.

\section{DISCUSSION}

The results obtained in this study strongly suggest that $B$. megaterium is more susceptible to $\mathrm{Ni}$ than to $\mathrm{Al}$ (Fig. 1), as can be observed by comparing $\mathrm{LC}_{50}$ and $\mathrm{LC}_{90}$ data, which demonstrate a 2-times more sensitivity of the microorganism to Ni. Evenmore, when cells were exposed to $175 \mathrm{ppm}$ of each metal, MNSH1-9K-1 showed a 7.5-fold decrement in cell viability with $\mathrm{Ni}$, compared to the survival observed with $\mathrm{Al}$. This $\mathrm{Ni}>\mathrm{Al}$ toxicity is in accordance with previous reports that show that $\mathrm{Ni}$ may be more toxic for biological systems than $\mathrm{Al}$ (Caicedo et al., 2008), since $\mathrm{Ni}$ is considered a hazardous metal (Amer 2002), as this metal has been related to 362 alterations in DNA repair mechanisms, epigenetic effects, and carcinogenesis (Macomber \& Hausinger 2011).

In the case of Al toxicity, its ions may bind to diverse cellular components, altering lipidprotein interactions, modifying the cellular transport activity, and blocking surface potential. Also, once inside the cell, Al ions can alter the metabolism by binding to enzymes or to enzyme substrates (Garcidueñas-Piña \& Cervantes 1996). 
So when strain MNSH1-9K-1 was exposed to Ni/Al mixtures, it was also evident a more pronounced viability loss as $\mathrm{Ni}$ concentration increased in samples (Fig. 2), showing MNSH1-9K-1 up to 24-times more sensitivity to a 5/125 (1:25) Al/Ni ppm than to a 125/5 (25:1) $\mathrm{Al} / \mathrm{Ni}$ ppm mixture. It has been documented that the B. megaterium genome contains open reading frames of genes involved in stress responses, including oxidative stress, osmotic stress, heat shock, and detoxification (Liu et al., 2011), which activations, at least in its most studied partner B. subtilis, overlap between general stress responses and more specific pathways (Young et al., 2013), and are highly intertwined under the control of central regulators like $\sigma^{\mathrm{B}}$, PerR, and extracytoplasmic sigma factors (Helmann 2002; Helmann et al., 2003; van der Steen \& Hellingwerf 2015).

The differences in cell survival when $B$. megaterium is exposed to diverse Ni/Al mixtures may be due to the diverse molecular mechanisms activated under certain metal stress conditions, directly related to the specific combination of $\mathrm{Ni}$ and $\mathrm{Al}$ concentrations present in the samples. As has been previously suggested, Bacillus cells may regulate their responsive systems depending on the rate and type of stress they are suffering, and even more, the microorganism may activate diverse pathways in response to stress increase or continuity (Young et al., 2013). For example, it was recently demonstrated that $\sigma^{\mathrm{B}}$ response is overlaid on the more specific stress responses, with a magnitude that increases with the speed at which salt and ethanol stress levels increase (Young et al., 2013).

With respect to $B$. megaterium $\mathrm{Ni}$ removal capability, reports have shown that this microorganism possesses high metal sorption capacity (Monachese et al., 2012), and $\mathrm{Ni}$ specific response genes have been identified in MNSH1-9K-1 by a polymerase chain reaction (PCR) approach (Fierros-Romero et al., 2016 a). However, these both mechanisms may not explain the results shown in the current study, since Ni uptake was only observed when $\mathrm{Al}$ was also present in the system. Also, it is very interesting to note that higher $\mathrm{Ni}$ removal efficiencies took place when $\mathrm{Ni}$ was present at 5 and $10 \mathrm{ppm}$, showing $25 \%$ and $20 \%$ removal efficiencies, respectively. At higher $\mathrm{Ni}$ concentrations, these efficiencies diminished to around $10 \%$, but nevertheless, the highest removal concentration was observed when $\mathrm{Al} / \mathrm{Ni}$ mixture was $10 / 100 \mathrm{ppm}$, where also the specific removal rate was calculated to be of $14,190 \mathrm{mg}$ of removed Ni per mg of dry cell weight.

Some metals, like $\mathrm{Fe}, \mathrm{Zn}, \mathrm{Cu}$, and $\mathrm{Mg}, \mathrm{Mn}$, and $\mathrm{Ca}$, are known to be widely used in biochemical processes in trace concentrations, being estimated that at least one-third of all proteins require metals (Waldron \& Robinson 2009); whereas other metals like $\mathrm{Ni}, \mathrm{Co}, \mathrm{Se}$ and Mo are only used by some organisms (Solioz et al., 2011). In the other hand, for toxic metals without a known function in biology, as $\mathrm{Pb}, \mathrm{Ag}, \mathrm{Cd}, \mathrm{Al}, \mathrm{As}, \mathrm{Cs}, \mathrm{Cr}, \mathrm{Hg}$, or $\mathrm{Pb}$ (Tchounwou et al., 2012), specialized defense mechanisms have evolved in many bacterial species (Waldron \& Robinson 2009). Although it is known that metal removal systems encountered in microorganisms are of varying specificity (Gadd 1990), the interaction of specific and non-specific heavy metal homeostasis mechanisms in bacteria are not clearly understood yet. Thus, it is possible that the observed Ni uptake ability may be the result of a non-specific metal removal mechanism that is enhanced in B. megaterium by $\mathrm{Al}$.

In conclusion, this study shows that $B$. megaterium MNSH1-9K-1 presents a more accentuated susceptibility to $\mathrm{Ni}$ than to $\mathrm{Al}$, and it is possible that besides the specific $\mathrm{Ni}$ removal mechanisms previously reported in this microorganism (Eppinger et al., 2011; Fierros-Romero et al., 2016 a, b), that may be activated under other precise conditions different from the ones tested during the current analysis, the strain MNSH1-9K-1 possesses interesting non-specific mechanisms that promote $\mathrm{Ni}$ uptake under stress 
conditions promoted by the presence of Al. In this regard, further -omic studies may be important to elucidate the Ni uptake mechanisms of B. megaterium, and even more, identify the bacterial pathways implicated in its capability to remove metals when present in mixtures. Also, further analysis may be important to evaluate the combination of physicochemical and biotechnological methods using B. megaterium, in order to improve the efficiency of current conventional waste water heavy metal removal techniques, for example, when low metal concentrations are present.

\section{ACKNOWLEDGEMENTS}

This project was supported by Grant 131203 from CONACyT, Mexico.

\section{CONFLICT OF INTEREST}

All the researchers listed as authors of the current study declare that there is no conflict of interests regarding the publication of this manuscript.

\section{REFERENCES}

Ameer Basha S. \& Rajaganesh, K. 2014. Microbial bioremediation of heavy metals from textile industry dye effluents using isolated bacterial strains. International Journal of Current Microbiology and Applied Sciences. 3(5): 785-794.

Amer, A. 2002. Processing of egyptian boiler-ash for extraction of vanadium and nickel. Waste Management. 22(5): 515-520.

Arenas-Isaac G., Gómez-Ramírez M., Montero-Álvarez L., Tobón-Avilés A., FierrosRomero G. \& Rojas-Avelizapa N. G. 2016. Novel microorganisms for the treatment of Ni and $\mathrm{V}$ of spent catalysts. Indian Journal of Biotechnology. In press.

Barakat M. A. 2011. New trends in removing heavy metals from industrial wastewater. Arabian Journal of Chemistry. 4(4): 361-377.

Bartha R. \& Ordal E. J. 1965. Nickel-dependent chemolithotrophic growth of two hydrogenomonas strains. Journal of Bacteriology. 89(4): 1015-1019.

Caicedo M., Jacobs J. J., Reddy A. \& Hallab N. J. 2008. Analysis of metal ion-induced DNA damage, apoptosis, and necrosis in human (Jurkat) T-cells demonstrates $\mathrm{Ni}^{2+}$ and $\mathrm{V}^{3+}$ are more toxic than other metals: $\mathrm{Al}^{3+}, \mathrm{Be}^{2+}, \mathrm{Co}^{2+}, \mathrm{Cr}^{3+}, \mathrm{Cu}^{2+}, \mathrm{Fe}^{3+}, \mathrm{Mo}^{5+}, \mathrm{Nb}^{5+}$, and $\mathrm{Zr}^{2+}$. Journal of Biomedical Materials Research Part A. 86(4): 905-913.

Cempel M. \& Nikel G. 2006. Nickel: a review of its sources and environmental toxicology. Polish Journal of Environmental Studies. 15(3): 375-382.

Coelho L. M., Rezende H. C., Coelho L. M., de Sousa P. A. R., Melo D. F. O. \& Coelho N. M. M. 2015. Bioremediation of polluted waters using microorganisms. In: Advances in bioremediation of wastewater and polluted soil. InTech, Rijeka, Croatia. 
Crafford D. \& Avenant-Oldewage A. 2010. Bioaccumulation of non-essential trace metals in tissues and organs of Clarias gariepinus (sharptooth catfish) from the Vaal River system-strontium, aluminium, lead and nickel. Water SA. 36(5): 621-640.

Dixit R., Wasiullah, Malaviya D., Pandiyan K., Singh U. B., Sahu A., Shukla R., Singh B. P., Rai J. P., Sharma P. K., Lade H. \& Paul D. 2015. Bioremediation of heavy metals from soil and aquatic environment: an overview of principles and criteria of fundamental processes. Sustainability. 7(2): 2189-2212.

Dogan M., Saygideger S. D. \& Colak U. 2009. Effect of lead toxicity on aquatic macrophyte Elodea canadensis Michx. Bulletin of Environmental Contamination and Toxicology. 83(2): 249-254.

Duruibe J. O., Ogwuegbu C. \& Egwurugwu J. N. 2007. Heavy metal pollution and human biotoxic effects. International Journal of Physical Sciences. 2(5): 112-118.

Eccles H. 1999. Treatment of metal-contaminated wastes: why select a biological process? Trends in Biotechnology. 17(12): 462-465.

Eisler R. 1998. Nickel hazards to fish, wildlife, and invertebrates: a synoptic review. Contaminant Hazard Reviews, Biological Science Report USGS/BRD/BSR-1998-0001.

Elsilk S. E., El-Shanshoury A. E. R. \& Ateya P. S. 2014. Research accumulation of some heavy metals by metal resistant avirulent Bacillus anthracis PS2010 isolated from Egypt. African Journal of Microbiology. 8(12): 1266-1276.

Enserink E. L., Maas-Diepeveen J. L. \& Van Leeuwen C. J. 1991. Combined effects of metals; an ecotoxicological evaluation. Water Research. 25(6): 679-687.

Eppinger M., Bunk B., Johns M. A., Edirsinghe J. N. Kutumbaka K. K., Koenig S. S., Creasy H. H., Rosovitz M. J., Riley D. R., Daugherty S., Martin M., Elbourne L. D., Paulsen I., Biedendieck R., Braun C., Grayburn S., Dhingra S., Lukyanchuk V., Ball B., Ul-Qamar R., Seibel J., Bremer E., Jahn D., Ravel J. \& Vary P.S. 2011. Genome sequences of the biotechnologically important Bacillus megaterium strains QMB1551 and DSM319. Journal of Bacteriology. 193(16): 4199-4213.

Fierros-Romero G., Gómez-Ramírez M., Arenas-Isaac G. E., Pless R. C. \& RojasAvelizapa N. G. 2016a. Identification of Bacillus megaterium and Microbacterium liquefaciens genes involved in metal resistance and metal removal. Canadian Journal of Microbiology. 62(6): 505-513.

Fierros-Romero G., Rivas-Castillo A., Gómez-Ramírez M., Pless R. \& Rojas-Avelizapa N. G. 2016b. Expression analysis of $\mathrm{Ni}$ - and V-associated resistance genes in a Bacillus megaterium strain isolated from a mining site. Current Microbiology. 73(2): 165-171.

Gadd, G.M. 1990. Heavy metal accumulation by bacteria and other microorganisms. 
Experientia. 46(8): 834-840.

Garcidueñas-Piña R. \& Cervantes C. 1996. Microbial interactions with aluminium. BioMetals 9: 311-316.

Gómez-Ramírez M., García-Martínez L., Fierros-Romero G., \& Rojas-Avelizapa N. G. 2014. Evaluation and identification of microorganisms able to remove $\mathrm{Ni}$ and $\mathrm{V}$ from hydroprocessing spent catalyst. In: Proceedings in biohydrometallurgy. June 9-11. Falmouth, Cornwall, UK.

Ceribasi I. H. \& Yetis U. 2004. Biosorption of $\mathrm{Ni}(\mathrm{ii})$ and $\mathrm{Pb}(\mathrm{ii})$ by Phanerochaete chrysosporium from a binary metal system - kinetics. Water SA. 27(1): 15-20.

Helmann J. D. 2002. The extracytoplasmic function (ECF) sigma factors. Advances in Microbial Physiology. 46: 47-110.

Helmann J. D., Wu M., Gaballa A., Kobel P. A., Morshedi M. M. Fawcet P. \& Paddon C. 2003. The global transcriptional response of Bacillus subtilis to peroxide stress is coordinated by three transcription factors. Journal of Bacteriology. 185(1): 243-253.

Hernández A., Mellado R. P. \& Martínez J. L. 1998. Metal accumulation and vanadiuminduced multidrug resistance by environmental isolates of Escherichia hermannii and Enterobacter cloacae. Applied and Environmental Microbiology. 64(11): 4317-4320.

Jackson V. A., Paulse, A. N., van Stormbroek T., Odendaal J. P. \& Khan W. 2009. Investigation into metal contamination of the Berg River, Western Cape, South Africa. Water SA. 33(2): 175-182.

Kamala-Kannan S. \& Jae Lee K. 2008. Metal tolerance and antibiotic resistance of Bacillus species isolated from Sunchon Bay sediments, South Korea. Biotechnology. 7(1): 149-152.

Kamaldeep, Rishi M. S. \& Ghosh N. K. A. N. 2011. Impact of industrialization on groundwater quality - a case study of Baddi-Barotiwala industria belt, Distt. Solan, Himachal Pradesh, India. Journal of Industrial Pollution Control. 27(2): 153-159.

Keim W. 1990. Nickel: an element with wide application in industrial homogeneous catalysis. Angewandte Chemie International Edition in English. 29(3): 235-244.

Kwong R. W. M. \& Niyogi S. 2009. The interactions of iron with other divalent metals in the intestinal tract of a freshwater teleost, rainbow trout (Oncorhynchus mykiss). Comparative Biochemistry and Physiology Part C: Toxicology \& Pharmacology. 150(4): 442-449.

Liu L., Li Y., Zhang J., Zow W., Liu J., Li X., Wang L., \& Chen J. 2011. Complete genome sequence of the industrial strain Bacillus megaterium WSH-002. Journal of Bacteriology 193(22): 6389-6390.

Macomber L. \& Hausinger R. P. 2011. Mechanisms of nickel toxicity in microorganisms. 
Metallomics: Integrated Biometal Science. 3(11): 1153-1162.

Margaryan A. A. Panosyan H. H., Birkeland N. K. \& Trchounian A. H. 2013. Heavy metal accumulation and the expression of the copA and nikA genes in Bacillus subtilis AG4 isolated from the Sotk gold mine in Armenia. Biological Journal of Armenia. 3(65): 51-57.

McConnell J. R. \& Edwards R. 2008. Coal burning leaves toxic heavy metal legacy in the Arctic. Proceedings of the National Academy of Sciences of the United States of America. 105(34):12140-12144.

Mejáre M. \& Bülow L. 2001. Metal-binding proteins and peptides in bioremediation and phytoremediation of heavy metals. Trends in Biotechnology. 19(2): 67-73.

Monachese M., Burton J. P. \& Reid G. 2012. Bioremediation and tolerance of humans to heavy metals through microbial processes: a potential role for probiotics?. Applied and Environmental Microbiology. 78(18): 6397-6404.

Moodley K. G., Baijnath H., Southway-Ajulu F. A., Maharaj S. \& Chetty S. R.. 2007. Determination of $\mathrm{Cr}, \mathrm{Pb}$ and $\mathrm{Ni}$ in water, sludge and plants from settling ponds of a sewage treatment works. Water SA. 33(5): 723-728.

Mulrooney S. B. \& Hausinger R. P. 2003. Nickel uptake and utilization by microorganisms. FEMS Microbiology Reviews. 27: 239-261.

Narita M., Chiba K., Nishizawa H., Ishii H., Huang C., Kawabata Z., Silver S. \& Endo G. 2003. Diversity of mercury resistance determinants among Bacillus strains isolated from sediment of Minamata Bay. FEMS Microbiology Letters, 223(1): 73-82.

Nicholson W. L. \& Setlow P. 1990. Sporulation, germination and outgrowth. In: Molecular biological methods for Bacillus. C. R. Harwood and S. M. Cutting, editors. Chichester, United Kingdom.

Olson J. W., Mehta N. S. \& Maier R. J. 2001. Requirement of nickel metabolism proteins HypA and HypB for full activity of both hydrogenase and urease in Helicobacter pylori. Molecular Microbiology. 39(1): 176-182.

Pal K. K, Dey R., Sherathia D., Vanpariya S., Patel I., Dalsania T., Savsani K., Sukhadiya B., Mandaliya M., Thomas M., Ghorai S., Rupapara R., Rawal P., Shah A. \& Bhayani S. 2014. Draft genome sequence of a moderately halophilic Bacillus megaterium strain, MSP20.1, isolated from a saltern of the Little Rann of Kutch, India. Genome Announcements. 2(1): 1-2.

Palaniappan P. L. R. M. \& Karthikeyan S. 2009. Bioaccumulation and depuration of chromium in the selected organs and whole body tissues of freshwater fish Cirrhinus mrigala individually and in binary solutions with nickel. Journal of Environmental Sciences (China). 21(2): 229-236. 
Perpetuo, E. A., Barbieri Souza C.B. \& Oller Nascimento C. A. 2011. Engineering bacteria for bioremediation. In: Progress in molecular and environmental bioengineering-from analysis and modeling to technology applications. InTech, Rijeka, Croatia.

Phuong P. K., Son C. P., Sauvain J. J. \& Tarradellas J. 1998. Contamination by PCB's, DDT's, and heavy metals in sediments of Ho Chi Minh city's canals, Viet Nam. Bulletin of Environmental Contamination and Toxicology. 60(3): 347-354.

Rajkumar M., Ma Y. \& Freitas H. 2013. Improvement of Ni phytostabilization by inoculation of $\mathrm{Ni}$ resistant Bacillus megaterium SR28C. Journal of Environmental Management. 128: 973-980.

Rubinstein J. B. \& Barsky L. 2002. Non-ferrous metal ores. Taylor \& Francis. New York, United States.

Salgaonkar B. B., Mani K. \& Braganca J. M. 2013. Characterization of polyhydroxyalkanoates accumulated by a moderately halophilic salt pan isolate Bacillus megaterium strain H16. Journal of Applied Microbiology. 114(5): 1347-1356.

Sharma S., Rana S., Thakkar A., Baldi A., Murthy R. S. R. \& Sharma R. K. 2016. Physical, chemical and phytoremediation technique for removal of heavy metals. Journal of Heavy Metal Toxicity and Diseases. 1(2): 1-15.

Singh S. K., Tripathi V. R., Jain R. K., Vikram S. \& Garg S. K. 2010. An antibiotic, heavy metal resistant and halotolerant Bacillus cereus SIU1 and its thermoalkaline protease. Microbial Cell Factories. 9(59): 1-7.

Singh Y., Ramteke P. W., Tripathy A. \& Shukla P. K. 2013. Isolation and characterization of Bacillus resistant to multiple heavy metals. International Journal of Current Microbiology and Applied Science. 2(11): 525-530.

Solioz M., Mermod M., Abicht H. K. \& Mancini S. 2011. Responses of lactic acid bacteria to heavy metal stress. In: Stress responses of lactic acid bacteria. Springer, Boston, United States.

Stefanescu I. A. 2015. Bioaccumulation of heavy metals by Bacillus megaterium from phosphogypsum waste. Scientific Study and Research. 16(1): 93-97.

Tchounwou P. B., Yedjou C. G., Patlolla A. K. \& Sutton D. J. 2012. Heavy metal toxicity and the environment. Experientia Supplementum. 101: 133-164.

Tsezos M. \& Volesky B. 1981. Biosorption of uranium and thorium. Biotechnology and Bioengineering. 23(3): 583-604.

van der Steen J. B. \& Hellingwerf K. J. 2015. Activation of the general stress response of Bacillus subtilis by visible light. Photochemical Photobiology Journal. 91(5): 1032-1045.

Rivas-Castillo et al. / Mexican Journal of Biotechnology 2017,2(2):206-220 
Vary P. S., Biedendieck R., Fuerch T., Meinhardt F., Rohde M., Deckwer W. \& Jahn D. 2007. Bacillus megaterium: from simple soil bacterium to industrial protein production host. Applied Microbiology and Biotechnology. 76(5):957-967.

Verma S. \& Dubey R. S. 2003. Lead toxicity induces lipid peroxidation and alters the activities of antioxidant enzymes in growing rice plants. Plant Science. 164: 645-655.

Waldron K. J. \& Robinson N. J. 2009. How do bacterial cells ensure that metalloproteins get the correct metal?. Nature Reviews Microbiology. 7(1): 25-35.

Yilmaz E. I. 2003. Metal tolerance and biosorption capacity of Bacillus circulans strain EB1. Research in Microbiology. 154(6): 409-415.

Young J. W., Locke J. C. W. \& Elowitz M. B. 2013. Rate of environmental change determines stress response specificity. Proceedings of the National Academy of Sciences of the United States of America. 110(10): 4140-4145. 